\title{
Incorporation of probiotic bacteria on larval culture of Macrobrachium amazonicum
}

\section{(Heller, 1862)}

Incorporação de bactérias probióticas no cultivo de larvas de Macrobrachium amazonicum (Heller, 1862)

Incorporación de bacterias probióticas en el cultivo de larvas de Macrobrachium amazonicum

(Heller, 1862)

Received: 10/13/2021 | Reviewed: 10/23/2021 | Accept: 11/06/2021| Published: 11/10/2021

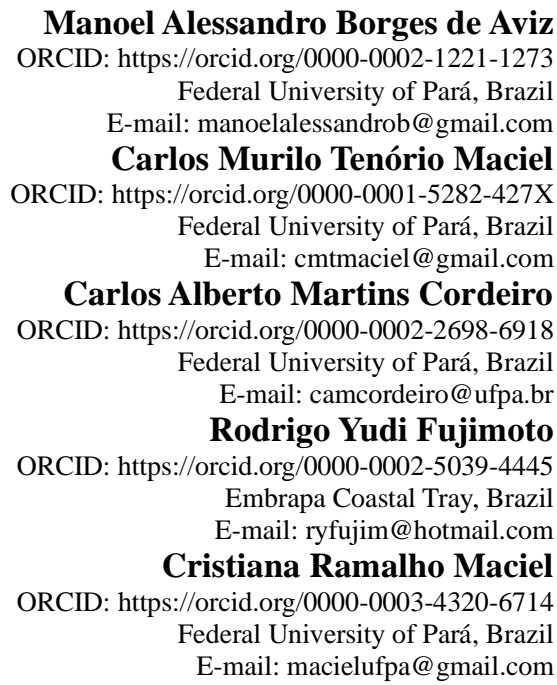

\begin{abstract}
In this study, we evaluated the utilization of two probiotics incorporated into the water and in the diet in a larval culture system of Amazon River prawn. Autochthonous probiotic bacteria from the gut of wild juveniles of $M$. amazonicum juveniles and a commercial probiotic were tested and the following parameters were analyzed: survival, productivity, fresh weight, length, larval condition index (LCI) and larval stage index (LSI). The colonization of the larval gastrointestinal tract by probiotics took place when they were incorporated into diet, while probiotics in the water proved to be unsuccessful. The use of lactic acid bacteria had no significant effects $(p>0.05)$ on survival, productivity, length, fresh weight, LSI and LCI, showing similar results in relation to the control group. However, we recommend the inclusion of probiotics into diet in larval culture of Amazon prawn since this method allowed bacterial gut colonization, which is important to evaluate the resistance to disease in further studies.
\end{abstract}

Keywords: Amazon River prawn; Larval culture; Lactic acid bacteria.

\section{Resumo}

Neste estudo avaliou-se o uso de dois probióticos na larvicultura do camarão-da-amazônia. Foram testados a bactéria ácido láctica autóctone Enterococcus faecalis, isoladas a partir do tubo digestório de juvenis de M. amazonicum selvagens e um probiótico comercial. As cepas probioticas foram diluídas diretamente na água e homogeneizada na ração fresca, na concentração de $1,85 \times 10^{6} \mathrm{UFC} / \mathrm{ml}$ e $1,85 \times 10^{6} \mathrm{UFC} / \mathrm{g}$, respectivamente. A inoculação na água ocorreu apenas no início do experimento, enquanto que na dieta, foi adicionado a partir do décimo dia em diante, diariamente. Parâmetros como: sobrevivência, produtividade, peso fresco, comprimento, índice de condição larval (ICL) e índice de estágio larval (IEL) foram avaliados. Ocorreu a colonização do trato gastrointestinal das larvas quando a inclusão dos probióticos foi feita a partir da dieta inerte, independentemente do tipo do probiótico, porém não houve efeito quando o procedimento foi realizado na água de cultivo. O uso de bactérias ácido lácticas não teve impacto significativo $(\mathrm{p}>0,05)$ sobre a sobrevivência, comprimento, peso fresco, IEL e ICL, apresentando resultados similares ao grupo controle. No entanto, o método de inclusão na dieta promoveu a colonização bacteriana no intestino, mas a inclusão diretamente na água também pode contribuir com a proteção externa dos animais e esse efeito é importante para avaliar a resistência contra patógenos em estudos futuros.

Palavras-chave: Camarão-da-amazônia; Larvicultura; Bactéria ácido lática. 


\section{Resumen}

En este estudio se evaluó el uso de dos probióticos en la larvicultura de camarón amazónico, probando su inclusión en el agua de cultivo y en la dieta inerte. Se probaron probióticos personalizados del tubo digestivo de juveniles silvestres de $M$. amazonicum y probióticos comerciales, además del grupo de control, sin la inclusión de probióticos. Se evaluaron parámetros como: supervivencia, productividad, peso fresco, longitud, índice de condición larvaria (ICL) e índice de estadio larvario (IEL). La colonización del tracto gastrointestinal de las larvas solo se produjo cuando se realizó la inclusión de probióticos a partir de la dieta inerte, sin éxito cuando el procedimiento se realizó en agua para cultivo. El uso de bacterias del ácido láctico no tuvo un impacto significativo ( $>$ > 0.05) en la supervivencia, productividad, longitud, peso fresco, IEL y ICL, mostrando resultados similares al grupo de control. Sin embargo, se determinó el método de inclusión de probióticos más adecuado para el estadio larvario, que podrían ser utilizados como probables inmunoestimulantes, aumentando la capacidad de defensa de las larvas frente a patógenos.

Palabras clave: Camarón amazónico; Larvicultura; Bacterias del ácido láctico.

\section{Introduction}

Macrobrachium amazonicum, popularly known as Amazon River prawn (Moraes-Valenti \& Valenti, 2010), is widely distributed in South America, ranging from Orinoco and Amazon basins to La Plata, central-western region and northern and northeastern coastal rivers in Brazil (Anger, 2013). This is a commercially important freshwater species, being exploited by artisanal fisheries in north and northeast Brazil (Maciel \& Valenti, 2009; Lima et al., 2014; Marques et al., 2020).

The Amazon River prawn is a potential species to intensive culture because it has proved to be suitable for domestication (Maciel \& Valenti, 2009). Therefore, this species has been a target of several studies, representing the third most studied species of Macrobrachium worldwide (Chong-Carrillo et al., 2015). Many aspects of their management have been established that assure successful larval culture and final growth processes (Moraes-Valenti \& Valenti, 2010). As a matter of fact, larval culture system is the most complex step since it required rigorous standards of several parameters, particularly in relation to water quality and larvae feeding. Previous reports indicated that salinity should vary between 10 and 12 , the pH should be around 7.5 to 8 and temperature should not exceed $30^{\circ} \mathrm{C}$ (Moraes-Valenti and Valenti, 2010). The larvae are obligatory and facultative lecithotrophic in zoea I and zoea II stages, respectively, when Artemia nauplii should be offered (Araujo \&Valenti, 2007; Queiroz et al., 2011). The Amazon prawn larvae have diurnal feeding habits and, besides Artemia nauplii, inert diet should be offered from zoea V on (Araujo \&Valenti, 2007; Maciel et al., 2012). Actually, the larvae seem to prefer this diet after reaching zoea VII, but the replacement of living food by inert diet is not recommended because it affects the survival rate and the quality of larvae (Araujo \&Valenti, 2007; Maciel \&Valenti, 2014). The productivity can reach 60 to 80 post-larvae /L in a 20-day interval (Moraes-Valenti \& Valenti, 2010). In spite of the development of culture system for this prawn species, there are no reports about the immune response of larvae or the effects of providing immunostimulants in controlled culture conditions.

Nonetheless, studies in other crustaceans indicated that the incorporation of probiotics in the water or in the diet might enhance culture systems (Nimrat et al., 2012; Adel et al., 2017). Accordingly, the utilization of probiotics instead of antibiotics might be an option to prevent diseases with no environmental effects. For instance, probiotics used in culture of Litopenaeus vannamei contributed to active their immune response and resistance to diseases, besides increasing their growth and survival rates (Fang et al., 2020).

Another advantage usually associated with the utilization of probiotics is their ability to enhance enzymatic activities, leading to increased alimentary efficiency (Nimrat et al., 2012; Kumar et al., 2016; Flegel, 2019). These benefits have been reported in several species of crustaceans, such as: Cherax tenuimanus (Ambas et al., 2013), Homarus gammarus (Daniels et al., 2013), Macrobrachium rosenbergii (Dash et al., 2014), Litopenaeus vannamei (Jamali et al., 2015; Xue et al., 2016; Bernal et al., 2017; Ramadhani et al., 2019), and Scylla paramamosain (Talib et al., 2017). 
However, the utilization of probiotics in culture systems required proper managements strategies. In some cases, their incorporation in the diet was more efficient than their release in the water. Probably, the probiotic bacteria in the diet might modulate directly both digestion and absorption of nutrients in the gut of shrimps (Chai et al., 2016). Another advantage of this strategy is the enhanced balance of intestinal microbiota and the increased production of extracell enzymes that potentialize the utilization of nutrients in the diet, leading to increased growth, thereby representing growth promoters (Giri et al., 2013; Ring $\varnothing$ et al., 2019). The inclusion of the probiotic Lactobacillus plantarum in the diet of M. rosenbergii in culture systems resulted in significant increases of weight, specific growth rate, alimentary conversion and amount of proteins in carcass (Dash et al., 2015; 2016). Likewise, the utilization of Lactobacillus sporogenes in this prawn species determined increased levels of growth, total proteins, total free aminoacids and total lipids, and feeding, conversion and excretion rates (Seenivasan et al., 2014).

In the case of M. amazonicum, bacteria that could be used as probiotics have already been isolated from the gut of wild juveniles (Silveira et al., 2015). On the other hand, neither the utilization of these bacteria lineages as probiotics in larval culture nor the putative benefits of their incorporation in the water or the diet have been tested. In this sense, the first step should involve the definition of management strategies of using probiotics focusing on the colonization of the digestive tract of larvae in culture systems. Therefore, the goal of this study was to evaluate the incorporation of autochthonous (speciesspecific) and commercial probiotics in the water and in the diet over the larval growth of M. amazonicum.

\section{Methodology}

This study was carried out under controlled laboratory conditions on the campus of the Federal University of Pará in Bragança. The focus was to verify the influence of probiotics during the cultivation of Amazon shrimp in the larval stage, quantifying the zootechnical indices to determine if there is an advantageous effect of the application of probiotics during the larval stage. This work is based on the review by Kumar et al., (2016), Luis-Villaseñor et al., (2011) and Ziaei-Nejad et al., (2006), Estrela, (2018), Pereira et al., (2018).

\subsection{Obtaining the larvae}

Ovigerous females of M. amazonicum were collected in Caeté River, Bragança - PA (1 ${ }^{\circ} 01^{\prime} 48.9^{\prime \prime}$ S, $\left.46^{\circ} 45^{\prime} 14.2^{\prime \prime} \mathrm{W}\right)$. Afterwards, the females were transported to the Laboratory of Aquaculture (Institute of Coastal Studies - UFPA) in thermal boxes with air flow system. In the laboratory, the females were disinfected by immersion in a solution of formalin $(30 \mathrm{mg} / \mathrm{L})$ for 30 minutes. Then, the specimens were placed in 50-L tanks equipped with biological filter and 5\% of salinity up to hatchery. After hatching, the larvae were acclimated to $10 \%$ of salinity and then transferred to experimental culture tanks.

\subsection{Experimental design}

The experiments were carried out in 50-L tanks equipped with biological filter um a close-dynamic system (Valenti et al., 1998). The brackish water used in culture system was previously filtered using mechanic filters (100 and $10 \mu \mathrm{m}$, respectively) and then passed through UV filter followed by disinfection using chloride solution ( $2 \mathrm{ppm})$. Each tank was populated by 4,000 larvae, corresponding to 80 larvae/L. The larvae were fed daily with recently-hatched nauplii of Artemia at a density of 4 to 12 nauplii/ml, being proportional to the day of culture and larval stage (Maciel et al., 2012). When the larvae reached zoea V stage, inert diet was offered, corresponding to a fresh food formula based on squids, fish, milk, wheat, egg, mineral and vitamin supplements (see Dhont et al., 2010).

The experimental groups were separated into two treatments and a control group, encompassing five replicates under the same culture conditions, as follows: 1- Control (CT - without incorporation of probiotics), 2- Incorporation of commercial 
probiotic bacteria (CP-DBAQUA®), and 3- Specific autochthonous probiotic bacteria (SP- Enterococcus faecalis) (Silveira et al., 2015).

In the treatment involving the commercial probiotic (CP), we used DB AQUA®, which includes de following bacteria lineages: Bacillus toyoi, Bacillus subtillis, Bifidobacterium bifidum, Enterococcus faecium and Lactobacillus acidophilus at a total concentration of $10^{8} \mathrm{UFC} / \mathrm{g}$. The probiotic was weighed to obtain an initial concentration of $1.85 \times 10^{6} \mathrm{UFC} / \mathrm{ml}$ after dilution in tank water. This product in enriched with aminoacids (lysine, methionine, colin) and $\mathrm{C}$ and $\mathrm{E}$ vitamins. The aminoacids and the vitamins present in the commercial probiotic were incorporated in the diet of the control and the specific (SP) groups to avoid differences in the concentration of nutrients in the diet among experimental groups.

In the case of the treatments using the customized probiotic (SP), we used Enterococcus faecalis obtained from the probiotic bacterial bank available in Laboratory of Probiotics from Universidade Federal do Pará, Bragança Campus. This lineage was isolated from wild juveniles ( 2-3 g) of Amazon River prawn. Initially, we performed in vitro selection (tests of in vitro pathogenic inhibition and catalase negative reaction), regarded as the first steps to select probiotic bacteria. The confirmation of lactic acid characteristics was carried out according to Silveira et al. (2015). The molecular identification of bacteria was established based on the procedure reported by Doyle and Doyle (1987). After growth and serial dilution, the final concentration of bacteria in each flask was measured. Aliquots equivalent to the amount required to reach $1.85 \times 10^{6} \mathrm{UFC} / \mathrm{ml}$ in water from culture systems were taken and centrifuged to remove the culture media and then diluted in the water used in larval culture system.

Both probiotics were added in the water of culture systems right after the including of larvae since larvae are able to feed upon inert food sources when they reach zoea V. From this stage on, the probiotics were incorporated only in the diet, while their incorporation into water was suspended. The inert diet was offered twice a day during 12 days up to the end of culture. For the inclusion of probiotics into the diet, the food was homogenized with CP and SP bacteria using the abovementioned concentration, while the offer of Artemia nauplii was regularly maintained.

\subsection{Test of in vivo colonization}

Before testing the commercial probiotic, $1 \mathrm{~g}$ of the commercial product was submitted to serial dilution in saline solution up to $10^{10}$. Afterwards, $1 \mathrm{ml}$ of each dilution was placed onto Petri dishes containing MRS culture medium. After $48 \mathrm{~h}$ at $30^{\circ} \mathrm{C}$, the bacterial growth was confirmed. Five larvae in zoea I stage were removed from each replicate per experimental group before the inoculation of probiotics. Subsequently, samples of larvae in zoea V stage (before the incorporation of inert diet) and post-larvae from all treatments and replicates (five per tank), including the control group, free of lactic acid bacteria, were taken. The procedures of growth and counting of colonies were performed according to Vieira et al. (2013). In these cases, for the counts of total lactic acid bacteria, $1 \mathrm{ml}$ of the macerated larval content was diluted in series up to a concentration of $10^{-6}$ in sterile saline solution. The diluted products were placed onto Petri dishes containing Man, Rogosa and Sharpe (MRS) Agar. After $48 \mathrm{~h}$ of growth at $30^{\circ} \mathrm{C}$, the total colonies were quantified. The same dilution procedure was carried out using $1 \mathrm{~mL}$ of tank water to count the colonies of total lactic acid bacteria.

\subsection{Culture parameters, larval condition index (LCI) and larval stage index (LSI)}

To evaluate the development of larval stages and the larvae culture conditions, we measured, in 2-day intervals, the indexes of larval stage (LSI) and larval condition (LCI), as follows: $\mathrm{LSI}=\left(\sum \mathrm{Si} \times \mathrm{ni}\right) / \mathrm{N}$, where $\mathrm{Si}$ is the larval stage $(\mathrm{i}=1-9)$, ni = number of larvae in the Si stage and $\mathrm{N}=$ number of observed larvae (Manzi et al., 1977) and $\mathrm{LCI}=\sum \mathrm{P} /(5 \mathrm{~N})$, where $\mathrm{P}$ was the score for the LCI adapted from Tayamen and Brown (1999), N = number of observed larvae. For these procedures, five larvae per replicate were used. 
At the end of the culture process, 10 post-larvae were selected at random from each tank to establish their total length and living weight. To obtain the total length, the post-larvae were measure using a digital pachymeter (precision of $0.02 \mathrm{~mm}$ ). To provide an accurate visualization of rostrum and telsum, we used a stereomicroscope (10x enlarged). The survival rates were also estimated. The parameters of water quality (temperature, $\mathrm{pH}$ and dissolved oxygen) were measured using a multiparameter probe (YSI Professional Plus), while total ammonia and nitrites were calculated using a colorimetric kit (Alcon).

\subsection{Statistical analysis}

The data related to length, living weight, survival, productivity, bacterial counts and water quality parameters were submitted to normality (Shapiro-Wilk) and homoscedasticity (Levene) tests, followed by ANOVA (1-factor) in the software Statistic version 7.0. Tukey's test was also carried out when statistical differences between mean values were observed.

\section{Results}

\subsection{Survival, productivity, larval indexes (LCI and LSI), weight and length}

The quality of the water in tanks remained similar among treatments for most of all analyzed parameters (temperature, $\mathrm{pH}$, dissolved oxygen and ammonia), with no significant differences between the daily mean values in each tank (Table 1). No significant differences were reported in the ammonia levels of water in culture systems in the treatments that received CP and SP probiotics when compared to the control group (free of probiotics) (CT). As for the nitrite in the water, a reduction was verified in the two treatments with incorporation of probiotics. The survival rate ranged from 69 to $73 \%$, without significant differences between mean values among treatments (CT, CP and SP) (Table 1). The larval condition index (LCI) was close to the ideal value (2) in all treatments, with records above 1.8 in all samples during the entire analyzed period (Figure 1a). As for the larval stage index (LSI), the changes for each subsequent stage occurred at a similar time, with the appearance of the first post-larvae (metamorphosis) being observed on the $14^{\text {th }}$ day of culture while the time to obtain most of post-larvae in each tank was equal to 22 days in all treatments (Figure 1b). No significant differences between the values of length and weight of postlarvae at the end of culture were observed (Table 1).

\subsection{Colonization of the gastrointestinal tract}

The culture media prepared from the gastrointestinal tract of larvae in zoea I stage showed no signs of growth of lactic acid bacteria. The use of probiotics in the water at the beginning of the culture (CP and SP) was unable to promote the colonization of the gastrointestinal tract of the larvae until the zoea V stage (approximately 10 days of culture), showing similar results to those obtained in the culture medium using the control group (CT).

The concentration of total lactic acid bacteria in the gastrointestinal tract of post-larvae and in the water at the end of the culture period (22 days) was significantly higher in treatments that received the commercial probiotic $(\mathrm{CP})$ when compared to those that received the customized probiotics (SP) (Figure 2). However, no growth of lactic acid bacteria strains was observed in the MRS culture medium for both samples (gastrointestinal tract and water) of the control group, showing that total lactic acid bacteria were quantified only in the treatments with probiotics.

\section{Discussion}

The water quality parameters remained adequate for the larval development of $M$. amazonicum in all treatments from this study, based on the values proposed by Moraes-Valenti and Valenti (2010). The survival rates were higher than 69\%, 
corroborating this statement. In addition, both commercial and autochthonous bacterial strains were able to colonize the gastrointestinal tract of the analyzed larvae.

In general. the use of probiotics in aquatic organisms are associated with several advantages, such as improved water quality and enhanced nutrition, growth and survival rates (Dawood et al., 2018; Toledo et al., 2018). These benefits are mainly related to the stimulation of enzymes that improved digestion and the absorption of nutrients, along with stimulation of immune responses (Luis-Villaseñor et al., 2011; Habib et al., 2014; Talib et al., 2017; Fang et al., 2020; Olmos et al., 2020). In the case of M. amazonicum larvae, the probiotics had no effects on zootechnical indexes (survival, weight, length, productivity, LCI and LSI) when compared to the control treatment (CT). Inasmuch as the larvae in the control group (CT) were raised under the suitable parameters established for the larval culture of this species, we obtained high performance in culture systems, possibly favored by the rusticity of the Amazon River prawn as corroborated by several reports that recorded high larval survival rates during their domestication process (Moraes-Valenti \& Valenti, 2010; Maciel et al., 2011; Maciel \& Valenti, 2012).

A major criterion for the utilization of probiotics in aquaculture tanks is their ability in reducing the concentration of nitrogen and phosphorus, thus controlling the levels of ammonia, nitrite and hydrogen sulfite (Tuan et al., 2013). As a matter of fact, previous reports showed that concentrations of nitrite and other nitrogen compounds decreased after incorporation probiotics into the water of shrimp culture systems (Zokaeifar et al., 2012). Nimrat et al. (2012) reported a significant reduction in the levels of ammonia and nitrite in tanks used for the larval culture of Litopenaeus vannamei after inoculation of Bacillus probiotics using distinct methods of application. Similar results were observed in the present study since both CP and SP probiotic strains promoted the reduction of nitrite contents in the larval culture of $M$. amazonicum, indicating that these probiotics might be used as bioremediatory strategies to maintain the water quality.

Possibly, the lack of records for other benefits of probiotics in shrimp larvae could be related to the short exposure time to lactic acid bacteria, as colonization of the digestive tract has taken place only at zoea V stage. In L. vannamei, Nimrat et al. (2012) observed no gains on length and weight of larvae after inoculation of probiotics, probably because of the short larval development period that prevented the establishment of significant differences in both parameters. Another possibility is that the larvae of M. amazonicum only respond to probiotic stimulation at more advanced larval stages.

Even though the inoculation of probiotics can be carried out directly in water, live food sources or in inert diets, the results are variable according to each species and developmental stage (Verchuere et al., 2000; Bidham et al., 2014). In the case of Penaeus monodon, M. rosenbergii, Fenneropenaeus indicus, Marsupenaeus japonicus, Litopenaeus vannamei, Portunus pelagicus, and Scylla paramamosain, the inoculation of probiotics into water was functional by improving zootechnical traits in cultured species (Ziaei-Nejad et al., 2006; Keysami et al., 2007; Luis-Villaseñor et al., 2011; Talpur et al., 2013; Talib et al., 2017). In larvae of M. amazonicum, the colonization of the gastrointestinal tract occurred only when the probiotics were incorporated to inert diet sources, leading to growth of lactic acid bacteria colonies in the digestive system of post-larvae. Therefore, it is necessary to evaluate the viability of introducing the lactic acid bacteria incorporated in Artemia nauplii in order to obtain earlier colonization in larvae of Amazon River prawn, thus increasing their exposure time to probiotics. In fact, analyses in shrimp species revealed that the administration of probiotics via diet is more effective than via water, as similarly reported in the present study (Toledo et al., 2018). This advantage is attributed to the fact that probiotic strains can directly modulate the digestion and absorption of nutrients in the digestive tract of shrimps and prawns (Chai et al., 2016; Toledo et al., 2018).

Possibly, the probiotics might act as immunostimulants for the Amazon River prawn, but since culture systems of this species are rarely affected by pathogens, we could not verify such possibility in this study. In the case L. vannamei, the use of probiotics resulted in increased expression of genes related to the immune system, improving the general conditions of larvae 
and their resistance to pathogens (Fang et al., 2020). Further studies using the Amazon River prawn raised with inoculation of probiotics, followed by the analysis of the differential expression of defense genes could determine whether this beneficial effect is present or not in this species. Another strategy to determine the putative advantages of probiotics over the immune response is to carry out pathogen-challenging experiment to evaluate the role of probiotics as immunostimulants. This information could be useful to anticipate management strategies under unfavorable conditions, thus assisting in early decisionmaking and increasing the chances of mitigating losses caused by pathogens. In fact, the initial colonization by probiotic organisms is likely to modulate gene expression in epithelial cells, thus creating a favorable environmental interface for the host (Hooper, 2015) then stimulating the immune system.

The main contribution of the present study was to establish that larvae of the Amazon River prawn respond to the colonization process of bacteria with probiotic potential after inoculation of strains via an inert diet. Furthermore, the colonization can be obtained by using either customized species-specific strains or commercial probiotics. Even though the commercial probiotics promoted a higher count of lactic acid bacteria strains in the digestive tract of post-larvae and in the water of tanks, this difference was not accompanied by zootechnical gains. Therefore, the cost of preparing customized probiotics or the investment in labor force can be relevant criteria for deciding the best method to be used in culture systems.

Another option that remains to be tested in further experiments is to develop a strategy of inoculating probiotics earlier in Artemia nauplii, which are offered to larvae from the second day of culture on. This management would allow to determine whether this procedure plays a protective role for the larvae by promoting immune responses or not. Nonetheless, we recommend that the incorporation of lactic acid bacteria in the inert diet would be the most appropriate management for the utilization of probiotics in larval culture systems of the Amazon River prawn.

\section{Conclusion}

The larvae of $M$. amazonicum respond to the colonization by probiotics when their inoculation is carried out into the inert diet. Although no improvements in the evaluated zootechnical indexes have been recorded, probiotics might enhance the larval immune response. Further studies about the immunostimulation process triggered by the incorporation of probiotics are required.

\section{References}

Adel, M., El-Sayed, A. F. M., Yeganeh, S., Dadar, M., \& Giri, S. S. (2017). Effect of Potential Probiotic Lactococcus lactis Subsp. lactis on Growth Performance, Intestinal Microbiota, Digestive Enzyme Activities, and Disease Resistance of Litopenaeus vannamei. Probiotics and Antimicrobial Proteins, 9(2):150-156. https://doi.org/10.1007/s12602-016-9235-9.

Ambas, I., Suriawan, A., \& Fotedar, R. (2013). Immunological responses of customised probiotics-fed marron, Cherax tenuimanus, (Smith 1912) when challenged with Vibrio mimicus. Fish and Shellfish Immunology, 35(2): 262-270. https://doi.org/10.1016/j.fsi.2013.04.026.

Anger, K. (2013). Neotropical Macrobrachium (caridea: palaemonidae): on the biology, origin, and radiation of freshwater-invading shrimp. Journal of Crustacean Biology, 33(2): 151-183. https://doi.org/10.1163/1937240X-00002124.

Araújo, M. C., \& Valenti, W. C. (2007). Feeding habit of the Amazon river prawn Macrobrachium amazonicum larvae. Aquaculture, 265(1-4): 187-193. https://doi.org/10.1016/j.aquaculture.2007.01.016.

Bernal, M. G., Marrero, R. M., Campa-Córdova, A. I., \& Mazon-Suástegui, J. M. (2017). Probiotic effect of Streptomyces strains alone or in combination with Bacillus and Lactobacillus in juveniles of the white shrimp Litopenaeus vannamei. Aquaculture International, 25(2): 927-939. https://doi.org/10.1007/s10499016-0085-y.

Bidham, C. D., Meena, D. K., Behera, B. K., Pronob, D., Mohapatra, P. K. D., \& Sharma, A. P. (2014). Probiotics in fish and shellfish culture: immunomodulatory and ecophysiological responses. Fish Physiology and Biochemistry, Springer. https://doi.org/10.1007/s10695-013-9897-0.

Chai, P. C., Song, X. L., Chen, G. F., Xu, H., \& Huang, J. (2016). Dietary supplementation of probiotic Bacillus PC465 isolated from the gut of Fenneropenaeus chinensis improves the health status and resistance of Litopenaeus vannamei against white spot syndrome virus. Fish and Shellfish Immunology, 54, 602-611. https://doi.org/10.1016/j.fsi.2016.05.011. 
Chong-Carrillo, O., Vega-Villasante, F., Arencibia-Jorge, R., Akintola, S. L., Michán-Aguirre, L., \& Cupul-Magaña, F. G. (2015). Research on the river shrimps of the genus Macrobrachium (Bate, 1868) (Decapoda: Caridea: Palaemonidae) with known or potential economic importance: strengths and weaknesses shown through scientometrics. Latin american journal of aquatic research, 43(4), 684-690 https://doi.org/10.3856/vol43-issue4-fulltext-7.

Daniels, C. L., Merrifield, D. L., Ringø, E., \& Davies, S. J. (2013). Probiotic, prebiotic and synbiotic applications for the improvement of larval European lobster (Homarus gammarus) culture. Aquaculture, 416 (December), 396-406. https://doi.org/10.1016/j.aquaculture.2013.08.001.

Dash, G., Raman, R. P., Pani Prasad, K., Makesh, M., Pradeep, M. A., \& Sen, S. (2015). Evaluation of paraprobiotic applicability of Lactobacillus plantarum in improving the immune response and disease protection in giant freshwater prawn, Macrobrachium rosenbergii (de Man, 1879). Fish and Shellfish Immunology, 43(1), 167-174. https://doi.org/10.1016/j.fsi.2014.12.007.

Dash, G., Raman, R. P., Prasad, K. P., Marappan, M., Pradeep, M. A., \& Sen, S. (2016). Evaluation of Lactobacillus plantarum as a water additive on host associated microflora, growth, feed efficiency and immune response of giant freshwater prawn, Macrobrachium rosenbergii (de Man, 1879). Aquaculture Research, 47(3), 804-818. https://doi.org/10.1111/are.12539.

Dash, G., Raman, R. P., Prasad, K. P., Marappan, M., Pradeep, M. A., \& Sen, S. (2014). Evaluation of Lactobacillus plantarum as a water additive on host associated microflora, growth, feed efficiency and immune response of giant freshwater prawn, Macrobrachium rosenbergii (de Man, 1879). Aquaculture Research, 47(3), 804-818. https://doi.org/10.1111/are.12539.

Dawood, M. A. O., Koshio, S., Abdel-Daim, M. M., \& Van Doan, H. (2018). Probiotic application for sustainable aquaculture. Reviews in Aquaculture, 11(3), 907-924. https://doi.org/10.1111/raq.12272.

Dhont, J., Wille, M., Frinsko, M., Coyle, S. D., \& Sorgeloos, P. (2010). Larval Feeds and Feeding. In M. B. New, W. C. Valenti, J. H. Tidwell, L. R. D'Abramo, \& M. N. Kutty (Eds.), Freshwater prawns: biology and farming (pp. 86-107). Wiley-Blackwell.

Doyle, J. J., \& Doyle, J. L. (1987). A rapid DNA isolation procedures for small amounts of fresh leaf tissue. Phytochemical Bulletin, 19(1), 11-15.

Estrela, C. (2018). Metodologia científica: ciência, ensino, pesquisa. (3rd ed.). Artes Médicas.

Fang, H., Wang, B., Jiang, K., Liu, M., \& Wang, L. (2020). Effects of Lactobacillus pentosus HC-2 on the growth performance, intestinal morphology, immune-related genes and intestinal microbiota of Penaeus vannamei affected by aflatoxin B1. Aquaculture, 525 (March), 735289. https://doi.org/10.1016/j.aquaculture.2020.735289.

Flegel, T.W. (2019). A future vision for disease control in shrimp aquaculture. Journal of the World Aquaculture Society, 50(2), 249-266. https://doi.org/10.1111/jwas.12589.

Franco, R., Martín, L., Arenal, A., Santiesteban, D., Sotolongo, J., Cabrera, H., Mejías, J., Rodríguez, G., Moreno, A. G., Pimentel, E., \& Castillo, N. M. (2016). Evaluation of two probiotics used during farm production of white shrimp Litopenaeus vannamei (Crustacea: Decapoda). Aquaculture Research, 48(4), 1936-1950. https://doi.org/10.1111/are.13031.

Giri, S. S., Sukumaran, V., \& Oviya, M. (2013). Potential probiotic Lactobacillus plantarum VSG3 improves the growth, immunity, and disease resistance of tropical freshwater fish, Labeo rohita. Fish and Shellfish Immunology, 34(2), 660-666. https://doi.org/10.1016/j.fsi.2012.12.008.

Habib, A., Das, N. G., \& Hossain, M. B. (2014). Growth Performance and Survival Rate of Macrobrachium rosenbergii (De Man, 1979) Larvae Using Different Doses of Probiotics. Pakistan Journal of Biological Sciences, 17(7), 920-924. https://doi.org/10.3923/pjbs.2014.920.924.

Hooper, L.V. (2015). Epithelial cell contributions to intestinal immunity. In: Advances in immunology, 126, 129-172. https://doi.org/10.1016/bs.ai.2014.11.003.

Jamali, H., Imani, A., Abdollahi, D., Roozbehfar, R., \& Isari, A. (2015). Use of Probiotic Bacillus spp. in Rotifer (Brachionus plicatilis) and Artemia (Artemia urmiana) Enrichment: Effects on Growth and Survival of Pacific White Shrimp Litopenaeus vannamei, Larvae. Probiotics and Antimicrobial Proteins, 7(2), 118-125. https://doi.org/10.1007/s12602-015-9189-3.

Keysami, M. A., Saad, C. R., Sijam, K., Daud, H. M., \& Alimon, A. R. (2007). Effect of Bacillus subtilis on growth development and survival of larvae Macrobrachium rosenbergii (de Man). Aquaculture Nutrition, 13(2), 131-136. https://doi.org/10.1111/j.1365-2095.2007.00463.x.

Kumar, V., Roy, S., Maena, D. K., \& Sarkar, U. K. (2016). Application of Probiotics in Shrimp Aquaculture: Importance, Mechanisms of Action, and Methods of Administration. Reviews in Fisheries Science and Aquaculture, 24(4), 342-368. https://doi.org/10.1080/23308249.2016.1193841.

Lima, J. F., Silva, L. M. A., Silva, T. C., Garcia, J. S., Pereira, I. S., \& Amaral, K. D. S. (2014). Reproductive aspects of Macrobrachium amazonicum (Decapoda: Palaemonidae) in the State of Amapa, Amazon River mouth. Acta Amazonica, 44(2), 245-254. https://doi.org/10.1590/S004459672014000200010

Luis-Villaseñor, I. E., Macías-Rodríguez, M. E., Gómez-Gil, B., Ascencio-Valle, F., \& Campa-Córdova, A. I. (2011). Beneficial effects of four Bacillus strains on the larval cultivation of Litopenaeus vannamei. Aquaculture, 321(1-2), 136-144. https://doi.org/10.1016/j.aquaculture.2011.08.036.

Maciel, C. R., \& Valenti, W. C. (2009). Biology, Fisheries, and Aquaculture of the Amazon River Prawn Macrobrachium amazonicum: A Review. Nauplius, 17(2), 61-79.

Maciel, C. R., \& Valenti, W. C. (2014). Assessing the potential of partil replacing of artemia by practical inert diet in the larviculture of the Amazon river prawn. Boletim do Instituto de Pesca, 40(1), 69-78. https://www.pesca.sp.gov.br/boletim/index.php/bip/article/view/1022,

Maciel, C. R., New, M. B., \& Valenti, W. C. (2012). The Predation of Artemia Nauplii by the Larvae of the Amazon River Prawn, Macrobrachium amazonicum (Heller, 1862), is Affected by Prey Density, Time of Day, and Ontogenetic Development. Journal of World Aquaculture Society, 43(5), 659-669. https://doi.org/10.1111/j.1749-7345.2012.00599.x. 
Manzi, J. J., Maddox, M. B., \& Sandifer, P. A. (1977). Algal supplement enhancement of Macrobrachium rosenbergii (De Man) larviculture. Proceedings of the World Mariculture Society, 8(1-4), 207-223. https://doi.org/10.1111/j.1749-7345.1977.tb00119.x.

Marques, M. H. C., Silva, I, C., Zacardi, D. M., Santos, M. A. S., Brabo, M. F., \& Maciel, C. R. (2020). Perfil do consumidor de camarão-da-Amazônia no Estado do Pará: socioeconômica, frequência de consumo e preferências. Research, Society and Development, 9(9), e525997316. https://doi.org/10.33448/rsdv9i9.7316.

Moraes-Valenti, P., \& Valenti, W. C. (2010). Culture of the Amazon river prawn Macrobrachium amazonicum. In M. B. New, W. C. Valenti, J. H. Tidwell, L. R. D’Abramo, \& M. N. Kutty (Eds.), Freshwater prawns: biology and farming (pp. 485-501). Wiley-Blackwell.

Nimrat, S., Suksawat, S., Boonthai, T., \& Vuthiphandchai, V. (2012). Potential Bacillus probiotics enhance bacterial numbers, water quality and growth during early development of white shrimp (Litopenaeus vannamei). Veterinary Microbiology, 159(3-4), 443-450. https://doi.org/10.1016/j.vetmic.2012.04.029.

Olmos, J., Acosta, M., Mendoza, G., \& Pitones, V. (2020). Bacillus subtilis, an ideal probiotic bacterium to shrimp and fish aquaculture that increase feed digestibility, prevent microbial diseases, and avoid water pollution. Archives of Microbiology, 202(3), 427-435. https://doi.org/10.1007/s00203-019-01757-2.

Pereira, A. S., Shitsuka, D. M., Perreira, F. J., \& Shitsuka, R. (2018). Metodologia da Pesquisa Científica (1st ed.). UFSM.

Queiroz, L. D., Abrunhosa, F. A., \& Maciel, C. R. (2011). Ontogenesis and functional morphology of the digestive system of the freshwater prawn, Macrobrachium amazonicum (Decapoda: Palaemonidae). Zoologia, 28(3), 395-402. https://doi.org/10.1590/S1984-46702011000300014.

Ramadhani, D. E., Widanarni, D., \& Sukenda, S. (2019). Microencapsulation of probiotics and its applications with prebiotic in Pacific white shrimp larvae through Artemia sp. Jurnal Akuakultur Indonesia, 18(2), 130-140. https://doi.org/10.19027/jai.18.2.130-140.

Ring $\varnothing$, E., Doan, H. Van, Lee, S., \& Song, S. K. (2019). Lactic Acid Bacteria in Shellfish: Possibilities and Challenges. Reviews in Fisheries Science and Aquaculture, 28(2), 139-169. https://doi.org/10.1080/23308249.2019.1683151.

Seenivasan, C., Radhakrishnan, S., Shanthi, R., Muralisankar, T., \& Saravana Bhavan, P. (2014). Effect of Lactobacillus sporogenes on survival, growth, biochemical constituents and energy utilization of freshwater prawn Macrobrachium rosenbergii post larvae. The Journal of Basic \& Applied Zoology, 67(2), 19-24. https://doi.org/10.1016/j.jobaz.2013.12.002.

Silveira, D. S., Silva, A. S., Dias, J. A. R., Souza, N. C., Fujimoto, R.Y., \& Cordeiro, C. A. M. (2015). Isolamento e estudos frente a patógenos in vitro de bactérias ácido láticas do Macrobrachium amazonicum (Heler, 1862) com potencial probiótico. Resumo do Congresso Brasileiro de Engenharia de Pesca. São Luiz.

Talib, A., Onn, K. K., Chowdury, M. A., Din, W. M. W., \& Yahya, K. (2017). The beneficial effects of multispecies Bacillus as probiotics in enhancing culture performance for mud crab Scylla paramamosain larval culture. Aquaculture International, 25(2), 849-866. https://doi.org/10.1007/s10499-016-0070-5.

Talpur, A. D., Ikhwanuddin, M., Abdullah, M. D. D., \& Bolong, A. A. (2013). Indigenous Lactobacillus plantarum as probiotic for larviculture of blue swimming crab, Portunus pelagicus (Linnaeus, 1758): effects on survival, digestive enzyme activities and water quality. Aquaculture, 416-417, 173-178. https://doi.org/10.1016/j.aquaculture.2013.09.018.

Tayamen, M., \& Brown, J. H. (1999). A condition index for evaluating larval quality of Macrobrachium rosenbergii (De Man, 1879). Aquaculture Research, 30(11-12), 917-922. https://doi.org/10.1046/j.1365-2109.1999.00411.x.

Toledo, A., Castillo, M. N., Carrillo, O., \& Arenal, A. (2018). Probiotics, a Reality in Shrimp Culture Review Article. Revista de Producción Animal, 30, 5973. https://doi.org/10.1016/j.aquaculture.2018.10.018.

Tuan, T. N., Duc, P. M., \& Hatai, K. (2013). Overview of the use of probiotics in aquaculture. International Journal of Research in Fisheries and Aquaculture, 3(3), 89-97.

Valenti, W. C., Mallasen, M., \& Silva, C. A. (1998). Larvicultura em sistema fechado dinâmico. In W. C. Valenti (Ed.), Carcinicultura de Água Doce: tecnologias para a produção de camarões (pp. 112-139). Fundacão de Amparo à Pesquisa do Estado de São Paulo (FAPESP), São Paulo e Instituto Brasileiro do Meio Ambiente e dos Recursos Naturais Renováveis (IBAMA).

Verchuere, L., Rombaut, G., Sorgeloos, P., \& Verstraete, W. (2000). Probiotic bacteria as biological control agents in aquaculture. Microbiology and Molecular Biology Reviews, 64(4), 655-671. https://doi.org/10.1128/mmbr.64.4.655-671.2000.

Vieira, F. N., Jatobá, A., Mouriño, J. L. P.,Vieira, E. A., Soares, M., da Silva, B. C., Seiffert, W. Q., Martins, M. L., \& Vinatea, L. A. (2013). In vitro selection of bacteria with potential for use as probiotics in marine shrimp culture. Pesquisa Agropecuaria Brasileira, 48(8), 998-1004. https://doi.org/10.1590/S0100$204 X 2013000800027$.

Xue, M., Wen, C., Liang, H., Ding, M., Wu, Y., \& Li, X. (2016). In vivo evaluation of the effects of commercial Bacillus probiotics on survival and development of Litopenaeus vannamei larvae during the early hatchery period. Aquaculture Research, 47(5), 1661-1669. https://doi.org/10.1111/are.12719.

Ziaei-Nejad, S., Rezaei, M. H., Takami, G. A., Lovett, D. L., Mirvaghefi, A. R., \& Shakouri, M. (2006). The effect of Bacillus spp. bacteria used as probiotics on digestive enzyme activity, survival and growth in the Indian white shrimp Fenneropenaeus indicus. Aquaculture, 252(2-4), 516-524. https://doi.org/10.1016/j.aquaculture.2005.07.021.

Zokaeifar, H., Babaei, N., Saad, C. R., Kamarudin, M. S., Sijam, K., \& Balcazar, J. L. (2014). Administration of Bacillus subtilis strains in the rearing water enhances the water quality, growth performance, immune response, and resistance against Vibrio harveyi infection in juvenile white shrimp, Litopenaeus vannamei. Fish and Shellfish Immunology, 36(1), 68-74. https://doi.org/10.1016/j.fsi.2013.10.007. 